\title{
Becoming Reflective Practitioners: A Case Study of Four Beginning Pre-service EFL Teachers in Turkey
}

\author{
Özkan Kırmızi ${ }^{1} \&$ Irfan Tosuncuoglu ${ }^{1}$ \\ ${ }^{1}$ Department of English Language and Literature, Karabük University, Karabük, Turkey \\ Correspondence: Irfan Tosuncuoglu, Department of English Language and Literature, Karabük University, \\ 78050 Karabük, Turkey.
}

\author{
Received: January 8, 2019 Accepted: March 14, 2019 Online Published: March 16, 2019 \\ doi: 10.5539/elt.v12n4p127 URL: https://doi.org/10.5539/elt.v12n4p127
}

\begin{abstract}
The present study was designed to investigate the emerging reflective practices of four pre-service English teachers during their practicum experience. The teachers were selected on the basis of convenience. Qualitative paradigm was adopted in the study. Observations, video recordings, and audio recordings were used as data collection tools. Each participant was observed four times and all the lessons were video-recorded. After each lesson, reflection sessions were conducted with the researcher, the pre-service teacher, and the mentor. These sessions were audio-recorded. As for the analysis of the data, content analysis was employed. As a result of the analysis of the data, use of L1, material use and planning, the pace and mood of the lesson, error correction, content and grading, and classroom management emerged as critical areas of reflection on the part of the participants.
\end{abstract}

Keywords: reflective practice, pre-service teachers, qualitative paradigm, L1 use

\section{Introduction}

Having been introduced by Dewey in 1933, the term "reflection" has become highly important in English Teacher Education and English Language Teaching (ELT). Dewey (1933) defined the term reflection as "the active, persistent and careful consideration of any belief or supposed form of knowledge in the light of the grounds that support it and the further conclusions to which it tends" (p. 9). In Dewey's terms, through reflection personal and impulsive behaviors or actions give way to rational and scientifically oriented actions. Borg (2011) states that reflective teachers systematically investigate their own teaching practices so that they can gain new insights and heighten their teaching quality. Reflection enables teachers to think critically (Korthagen, 2004), provides a source of knowledge construction in teaching, and develops self-regulation in teachers (Singh, 2008; Boud, 2007).

Recently, research on language teacher education has shifted to the contributions of the learners, teachers and the larger socio-political context to the complex foreign language learning/teaching process (Gao, 2008; Zhang \& Said, 2014) as opposed to merely focusing on language teaching theories or methods. With this new inclination, the role of context and other stakeholders has become highly relevant and started to produce highly beneficial data. These changes, according to Kumaravadivelu (2006) and Ryder (2012), played a role in the rise of research on reflective teaching in foreign language education.

Most scholars suggest that practicum sessions play a fundamental role in helping pre-service teachers to form personal theories in their initial teacher education process (Levin \& He, 2008; McKenzie \& Santiago, 2005). Among the benefits offered by practicum are situational and authentic learning possibilities and the application of conceptual tools to real-world situations (Kim \& Hannafin, 2008; Turunen \& Tuovila, 2012). During this process, it is vital that student teachers reflect on their experiences as they apply theoretical concepts to their practice (Turunen \& Tuovila, 2012).

In the present study, reflection sessions were conducted in the presence of the pre-service teacher, mentor and the university advisor (the researcher). The reason why mentors are included in the study is that mentors provide students with a professional first-hand help. Moreover, it is argued that conducting reflections with mentors benefits both pre-service teachers and mentors as well.

Reflection is an indispensable part of teachers' thinking and a crucial component of teacher education 
programmes. Reflection enables student teachers to observe and evaluate their experiences and draw conceptual frameworks to increase their awareness, beliefs and assumptions. Literature indicates that practicum sessions help student teachers to develop their reflective skills through tutoring discussions with peer students and supervisors (Pence \& Macgillivray, 2008; Turnbull, 2005).

The current view in teacher education today is to views teacher trainees as "active, thinking decision makers" (Borg, 2003, p. 81) rather than receivers or imparters of knowledge. And according to Moradkhani et al. (2017), the emergence of postmodern paradigm strengthened this new perspective. This new perspective, as is indicated by (Kumaravadivelu, 2006, p. 173), requires teachers to "theorize from their practice and practice what they theorize".

However, there seems to be a scarcity of empirical research on the relationship between teachers' involvement in reflective practices and the improvement of their teaching performance or students' achievement (Akbari, 2007; T. M. Winchester \& M. K. Winchester, 2014). There may be several reasons for this. In the first place, Farrel (2016) claims that the reason may be lack of a sound basis of performance in teaching along with methodological and logistic problems. As a result, it is hard to draw causal relationships between teachers' reflective practices and students' achievement. Therefore, the present study nnaims to fill the gap in research on the development of reflective processes of pre-service teachers.

\subsection{Theoretical Background}

The term "reflective practice" dates back to Dewey (1933), who viewed reflection as a meaning-making process whereby learners deepen their understanding of their experiences. According to Dewey (1933), in order to become reflective, one must adopt a systematic, rigorous, and disciplined way of thinking. This requires being able to think events back, make judgments about them, and modify future teaching behaviors in light of an awareness of one's own ideas and attitudes.

Recently, different scholars defined reflection differently. Milrood (1999, p. 10), for example, views reflection as "the process of mirroring the environment non-judgmentally or critically for the purpose of decision-making." Farrell (2012: 15) defined reflective practice as "a compass of sorts to guide teachers when they may be seeking direction as to what they are doing in the classrooms". In these definitions, the terms like "critically for the purpose of decision-making" and "seeking direction as to what they are doing in the classrooms" seem to indicate the same idea; the idea that reflection make it possible for teachers to decide their future actions.

According to Schon (1987), reflection is presenting and coping with the problems of practice, of allowing the self to be more open to different possibilities during the process of presenting teaching problems and then putting those problems in context in order to discover actions to improve the situation. Schon uses two important terms: (a) "reflection on action" and (b) "reflection in action". As the name implies, "reflection on action" occurs after a teaching event finishes whereas "reflection in action" takes place during the act of teaching and entails interpreting, analyzing, and providing solutions to the complex situations in the classroom.

\subsection{Literature Review}

Literature suggests that school-related experiences play a role in students' learning processes and that memories link new knowledge to prior experiences (Hudson et al., 2010), that former teachers can be role models (Chang-Kredl \& Kingsley, 2014; Uitto, 2011). More importantly, practicum sessions during preservice teacher education form an important basis for practical theories (Levin \& He, 2008). In a similar vein, Körkkö et al. (2016) conducted a study on professional development through reflection and found that student teachers experienced development in their reflections, albeit somewhat descriptive. They found that the reflection and feedback provided in practicum encouraged teacher trainees to develop practical theories and to get an understanding of how theory is put into practice. From these results, it can be concluded that student teachers benefit from the support they receive in their professional development.

Kimmelmann and Lang (2019) conducted a study on the effectiveness of cooperative learning in teacher education. Their study found that teachers and student teachers benefit in many ways through cooperative learning. One particular benefit of this is that both teachers and student teachers in the study is having multiple perspective and the opportunity to exchange their experiences and opinions. This is an example of dialogic nature of teacher education.

In Turkish context, the reflections of pre-service teachers was studied by Akcan (2016). It was conducted to investigate pre-service teachers' reflections in terms of their teacher education programs. This study identified the major challenge of pre-service teachers as lesson delivery, managing behaviour, unmotivated students, and students with learning disabilities. 
In an important analysis, Clarke and Hollingsworth (2002, p. 947) stated that "If we are to facilitate the professional development of teachers, we must understand the process by which teachers grow professionally and the conditions that support and promote that growth". Accodingly, the aims of the present study are basically twofold. In the first place, the study aims to get an understanding of the reflective practices of pre-service teachers. Secondly, the study aims to facilitate and pre-service teachers' reflection during their final year practicum. This practicum was designed to take place in a high school. In Turkey, pre-service teachers are exposed to practicum in the first year and in the final year of their education. In practicum, mentors are assigned to pre-service teachers and they are also guided by lecturers of the faculty of education. The practicum lasts for one term. In Turkish context, there does not seem to be sufficient number of studies that focus on the emerging reflective practices of pre-service EFL teachers, especially from a qualitative perspective.

As such, the present study attempts to answer the following questions:

1). What are the initial reflections of pre-service EFL teachers as they go through their practicum experience?

2). Depending on their initial teaching experiences in the practicum process, in what areas do pre-service EFL teachers need professional development?

\section{Methodology}

\subsection{Research Design}

This study was designed as a qualitative case study involving four pre-service L2 teachers in their practicum within the scope of teacher education program. Qualitative research is valued by a number of researchers (Creswell, 2003; Dörnyei, 2007; Hatch, 2002; Mackey \& Gass, 2005). In this fourteen-week practicum, these candidate teachers are placed into schools and they are supposed to stay in the school one day of the week entering courses. During their stay, they observe different aspects of the instructional process. In one week, for example, they observe certain activities, in another they observe elements of classroom management employed by their mentor teachers. Each student is assigned to one mentor teacher at the practicum schools and each mentor teacher has from three to four teacher candidates in their classrooms. Students are supposed to conduct lessons at least four times during this fourteen-week process, with the classroom teacher-mentor guiding them in implementing the curriculum.

\subsection{Participants and Research Setting}

The participants of the study were four pre-service teachers going through their practicum. The pre-service teachers confirmed that they volunteered to take part in the study. The participants are English Language and Literature department students who have taken their teacher certificate program. This program consists of two semesters. In the first semester, students are exposed to courses like educational psychology, testing, teaching methods and techniques, etc. In the second semester of the teacher certificate program, students take two courses along with their practicum experience. The courses taken in the second semester are "materials design" and "Teaching language skills". All the participants are at the ages of 22 and 23. None of them had previous teaching experience before they started their teacher certificate program.

In order to schedule the teaching hours of the participants, an overall plan was made with the pre-service teachers, the researcher, and the mentors. The researcher visited the classroom to observe the implementation. The instruction generally followed the curriculum specified by the Ministry of Education. All the materials are provided by the ministry. The classes are equipped with smart boards. Pre-service teachers were warmed up to the actual teaching week by week. They taught short sessions before taking on a full-lesson teaching. As of the sixth week, they started their full-lesson teachings. Collaboration was ensured among mentors, the researcher, and the pre-service teachers in preparing the lessons.

\subsection{Data}

The data in the present study was collected through semi-structured interviews, stimulated recalls, reflection sessions, and video records, and evaluations provided by mentors. The reflection sessions consisted of 12 hours of videotaped mentoring discussions among the pre-service teachers, mentors, and the researcher. As a first step, the pre-service teachers were video-recorded as they were teaching. Each pre-service teacher taught four times during the whole practicum process. Therefore, as a total, the researcher observed and recorded 16 lessons given by the four participants. Stimulated recall technique was used right after the implementation of each lesson so that no data would be lost as was proposed by Gass and Mackey (2000). The videos were watched and discussed by the pre-service teacher, mentor, and the researcher after the instruction. The main data for the study, however, did not come from the video-recorded lessons, but from the discussion sessions conducted with the pre-service teacher, mentor, and the researcher. In total, nearly 12 hours of video-recorded sessions were obtained. 


\section{Findings}

The findings related to each emerging aspect are presented and dicussed in this part. The following are the main themes that emerged from the reflections and observations of the pre-service teachers:

- $\quad$ use of L1

- material use and planning

- the pace and mood of the lesson

- $\quad$ error correction

- content and grading

- classroom management

\subsection{L1 Use}

One of the most important problems faced throughout the process was related to L1 use. Unfortunately, in Turkish education system most teachers prefer to use L1 in the classroom and most students do not have a chance to hear English. And as a result, they are not used to hearing English. During this practicum, the pre-service teachers were also somehow resistant to the use of L2 in the class for fear that the students would not understand them. They used to switch to Turkish once students did not understand; they did not persis. However, with the guidance of the university advisor, the pre-service teachers were compelled to use more L2 in the classroom and the students got used to hearing English at the end of the term; that is, most of the class time could be spared to L2 use. Regarding L1 use, the pre-service teachers stated the following:

First, we piloted. It was completely in English. I couldn't use English at all. It didn't go as I planned. It lasted too long. I tried to speak English $n$ the first week. Then I realized it was not necessary to speak English totally. I think that we should switch to L1 when needed.

Another participants stated the following:

I went a little Turkish and a little English. I don't think they understand English. I know that we can overcome this. We can use simple instructions and more mimicry. For practice, more L2 must be used in the classroom.

As time went by, better notes came from the pre-service teachers in terms of L'2 use in the classroom. One of the participants, for example, stated the following as for L2 use:

I tried to use L2. They don't understand but when they don't understand they grow curious as to what your second sentences is going to be. They start listening. I think they start understanding better. Initially, they were terrible in terms of understanding L2. Instructions must be given in L2. Now, I believe that I can establish proper use of L2. During this process, I saw that students try to understand what you are saying in L2.

\subsection{The Pace and Mood of the Lesson}

Another important issue that emerged from the observations and reflection sessions was "the pace and mood of the lesson" At the beginning of the term, the pre-service teachers had hard times in finishing lessons on time, managing the time effectively and so on. Related to this, the mood of the lessons was also a little down; the lessons were rather silent and slow. The perennial problem that led to low mood on the part of the pre-service teachers was lack of participation on the part of students. The teachers were instantenously demotivated when students did not participate. One of the participants, for example, stated the following:

It didn't go as I planned. There are silence and lack of participation. I forgot what I was going to do. In fact, nothing went as I wanted. My ideas were good, but they didn't work in the classroom. I could have continued with the example or I could have made up stories. I thought that they would be able to guess the meaning from the pictures, but they couldn't.

Another participant stated the following regarding the pace of the lesson:

The students were able to take notes. Yet, I am not sure about the pace of the lesson. I spared time for them to write. I could have given them some more extra time. I wasn't able to make them participate the lesson. They chatted.

As for the mood of the lesson, another participant stated the following:

To begin with, I expected more participation from the class. They were much better last week. They didn't participate this week. The timing shifted, and I understood that I needed extra activity. I became de-motivated and started speaking Turkish. They don't understand the rule in grammar lessons when I use L2. They are not 
used to hearing English. They powerpoint slides ended very quickly. The students did not also participate the exercises. I should have persisted in using $L 2$ and been more patient. I didn't have a contingency plan.

The fall of the mood of the pre-service teachers was frequent. Another teacher who got demotivated as a result of the unexpected divergences in the plan said that:

I taught "Wh- questions" and I knew that I would not be able to finish it on time; and as I expected I could only cover half of the issue. We started the lesson a little late and I became demotivated because I couldn't finish the planned part. I hadn't planned it this way. I started the topic wrongly. I drew a diagram; but it would have been better if I had used a story.

Similar views were also voiced by another participant as follows:

I was afraid of speaking English. When I received negative feedback from students, I switched back to Turkish. The lesson does not have any strong points. It didn't go as I planned. I have a negative impression regarding this lesson. The instruction should have been clearer and more understandable. I don't want to use students' L1. There should have been more examples and more visuals in the presentation of the grammar point. Visuals appeal to all student groups. Moreover, there should have been various activities. I was afraid of time constraint. But there should have been alternatives. In the previous lesson, I hadn't done review. But I found out that we must review the points that have been studied in the lesson. I think it is necessary. The exercises are too mechanical; instead, there should be more communication-oriented activities. The silence of the students frightens me.

\subsection{Material Use and Planning}

Another critical issue was related to materials and planning. As for the materials, the problem was twofold: both the preparation and the use of materials. At the beginning of the process, pre-service teachers thought that anything they found on the Internet would do. They used to print out and tried to use the materials without checking. However, the problems were quick to arise. One thing was that the materials they found were not proper in terms of layout and content. As the process unfolded, they made remarkable progress in terms of effective use of materials and planning. Sample answers related to material use and planning are as follows:

As for the use of materials, the first participants stated the following:

The visuals are very effective; that is why I used visuals. In the previous lessons, I used video and found out that it facilitates retention. But, some of the take notes and some don't. The teacher has to hit the balance and I couldn't do it in this observation.

\subsection{Error Correction}

Another area of concern was error correction. The general view regarding error correction is that pre-service teachers believe that they know when and how to correct students. However, their implementation was not always consistent. In general, they avoided correcting students' mistakes. What is more, they did not correct students when they were supposed to. One of the mistakes that pre-service teachers failed to correct was the incorrect use of the "ing". Most Turkish students pronounce "ing" incorrectly. They did not conduct general error correction, i.e. at the end of an activity or a lesson. Sample views from the participants are as follows:

I used the explanation method. I corrected them instantaneously as they were doing reading. I believe that it is more retainable this way. But the student did not correct his mistake. I don't know how else I can approach the issue of error correction.

With regard to error correction, one participant stated the following:

I corrected their pronounciation mistakes as they were reading. But I am not sure whether this was useful or not. I also tried to conduct general correction. I could have also corrected the students as they were doing the exercises.

\subsection{Content and Grading}

Some practical issues related to language also emerged. They are related to the presentation and organization of the content. The participant stated that:

It is important that we present language points in the form of daily language. We only teach the structure. In one of the videos I watched, they said that more dialogues must be included. Students do not know daily language. I could have given more information about endangered animals (this was the point of the lesson). I could have explained the aim of the lesson as well.

Another participant stated the following: 
Definitely, there should have been more time for "to be". I should have explained it much better. In fact, they studied it before, but they did not learn it properly. I could not imagine that they would be so weak in terms of the use of "to be". I thought they could draw analogies with "am/is/are, but they didn't. It appears that knowing students is highly important. They studied "have / has got" before, but they couldn't see the connections.

The next issue is related to remedial teaching. The pre-service teacher stated the following as for remedial teaching:

I decided to do remedial teaching when I saw that they were having problems doing the exercise. I thought that they hadn't grasped the point. It would have been better if I had done this as I was doing the actual teaching. I should have taught the different ways of adding " $s$ " to the verb in the simple present tense. Things do not go as we plan.

As for content and grading, another problem that pre-service teachers face is not planning intergration of activities. They were reminded of skill integration during reflection sessions both by the mentor teacher and the university advisor. As a result, the following remarks came from the students:

The integration of writing to vocabulary went well. Students wrote well. During this time, I walked around the class and monitored them. I saw that they could produce the language, and this made me very happy. With their participation, the lesson went well.

After several weeks of reflections, one of the participants stated the following in terms of content and grading.

In this lesson, we studied 'adverbs of frequency'. They found it very interesting and did not find it hard. They participated. They didn't have difficulties in translating the sentences. I tried to teach the vocabulary through English and it worked. I used 'Harry Potter' because I tried to appeal to their interest area.

One of the mentors remarked the following in terms of the content and grading of one of the lessons:

You could have practiced the pronunciation of the words once more. Using different colors for different words was a good idea for retention. However, you did not mention the place of such adverbs in sentences. You could have taught this. The lesson was good. The visuals enabled students to understand the topic at hand easily.

In relation to content and grading, the lack of production can also be included. Pre-service teachers did not have an idea of how to integrate production in their lessons. They even did not see the need at the beginning of the practicum process. However, the reflections with the university advisor and the mentor made it clear to them that production is a must in lessons. One of the participants stated the following in this regard:

The lesson was rather mechanical. I realized this. My mentor reminded me to include more production activities. Now, I see the need for this. Next time, I will include more production.

\subsection{Other Practical Issues}

Along with the aforementioned issues, there are some other practical issues that emerged in the process in the development of pre-service teachers in the course of the present study. These are the use of voice and the use of the board. Sample reflections from the participants are as follows:

I started to use more body language as I am giving instructions. This enhanced their understanding. I now use my voice better. I also developed in ther use of the board.

Another participant stated the following in terms of pratical issues:

I could have used the board much better. I realized that it was rather messy. I also got confused as to how to write and say the dates (this was the point being taught). The exercises lasted too long. I taught the use of the verb "tell", but it was irrelevant. I could have reminded them of the ordinal numbers.

Unfortunately, students do not use the demo technique even though there are times that they can use. One reason for this may be the presence of the advisor and the mentor in the classroom.

The idea of presentation and using famous people in it was good. I chose characters from youth TV series. There were no problems in the use of materials. The instructions could have been clearer.

One of the participants implicitly revealed the role of inductive process in langague teaching by stating the following:

Next time, I want to present them with choices instead of answering questions myself when they cannot find the answer. I preferred to explain everything explicity myself. However, if I had given them chances to make deductions, it would have been better. I thought that they would not have been able to do so. But, now I realize that I must give them more examples and make them deduce the points to be learned. 


\subsection{General Reflection}

The practicum process enabled the pre-service teachers to improve themselves in a number of areas. They had positive remarks in their general reflection sessions. The following are sample answers provided by pre-service teachers:

In the following quotation, for example, the participant stresses the importance of technological pedagogical knowledge, knowledge of lesson plan, and time management.

I was more confident compared to last week. We live problems with the smart boards. My plan finished early; I expected it to finish on time. But this was no problem because I used the remaining time for review.

The following excerpt makes it clear that the pre-service teachers improved themselves in terms of L2 use. It also indicates that in her future career, the pre-service teacher intends to focus on error correction and giving feedback. Moreover, error correction is also mentioned in this quotation.

In general, I believe that I made progress. I particularly develop in the use of L2. I use more L2 now. I got better in time management. I got a better idea of what it means to plan a lesson. I seem to be oblivious of error correction issues. I need improvement here. In my future professional development, I will particularly focus on error correction and giving feedback.

The following quotation shows that instructions are still a problem for pre-service teachers. This quotation also includes the preparation and use of materials.

We still have problems in giving instructions. At the beginning, I didn't think that giving instructions was so difficult. In general, I got better in terms of preparing and using materials. At the beginning of the process, we used to bring anything we found on the Interent to the class. We are more selective now. We also improved ourselves in terms of interaction with students. We know them better, and we have a better idea of their level; we can guess what they can do and what they cannot do. This plays a great role especially in our use of L2. We are not as nervous as we used to be.

The following quotation shows that pre-service teachers made progress in terms of increasing participation.

They did the exercises. It was a nice lesson. In previous lessons, most of the students did not participate; but now they started participating. I explained the topic when they did not understand. I tried to give better instructions. However, there is still no production.

The following quotation indicates that the practicum process reduces pre-service teachers's stress level. It also shows that pre-service teachers became better in managing time.

In my second lesson, I felt much comfortable. I was very nervous at the first one. This lesson went well and according to my plan. I had prepared extra questins in case there was extra time at the end of the lesson. I think that they grasped the topic. Since some question patterns were too long, I explained them in English. But I think I spoke too much Turkish. I had difficulty in managing the class; I couldn't silence them. We taught 13 different structures on that day. I found different materials. I tried to tailor them to their level. They found them difficult when I presented 13 of them at once. I could have been more selective and leave some of them for a later time. I still have problems giving instructions.

In terms of general evaluation, the mentor of one of the participants stated the following:

The use of materials has become clearer. The pre-service teachers started to use more visuals such as tables or diagrams. Their use of English also has become more understandable. Pre-service teacher can not get more participation from the students. Timing is getting better. They still need guidance in terms of the practice of error correction.

\subsection{Focus Group Interview}

At the end of the practicum, a focus group interview was conducted with the pre-service teachers as a final evaluation of the process. One of the most important findings of the focus group interview was that the pre-service teachers believe that they have had remarkable progress in the teaching experience. Another important finding of the study was that, as is already evident from the related literature, previous experiences play a significant role in the formation of teacher identity. When it comes to reflection and professional development, the pre-service teachers think that they can benefit from experience, collaboration, the Internet, andreading literature. Finally, the themes that emerged from the focus group interview are as follows:

\subsubsection{The Duration of the Practicum}

As for the duration of the practicum, the pre-service teachers stated that it was remarkably beneficial. However, 
they stated that it was too short. It must be extended over two terms. What is more, they stated that the observation period that precedes the actual presentations of the pre-service teachers was too long ( 5 or 6 weeks). They are of the opinion that it can be shortened so that more time can be spared for their actual teachings.

\subsubsection{The Connection Between Theory and Practice}

The pre-service teachers stated that practicum provided them a wealth of opportunities in order to combine theory and practice. In particular, they believe that the theory-practice connections were established in classroom management. The participants also stressed that the theoretical background is essential to support the classroom experience.

\subsubsection{Planning}

One of the most important components that the practicum enhanced was planning. The pre-service teachers state that they gained a lof of new insigths in terms of time management and other elements of classroom management Another issue under planning is how to start a lesson and how to get students' attention. The pre-service teachers seem to have realized the importance of getting students' attention. One of the participants stated that:

The introduction to the lesson is very important, especially when you are going to present a grammar point or some vocabulary items. In my future development, this is one of the areas that I would like to focus on. That is why throughout the practicum process, I did my best to find interesting materials for the students.

\subsubsection{Knowledge of Students}

Knowledge of students also emerged as a crucial component of the teaching process. Among the issues related to knowledge of students are knowing the level of students, knowing their interest areas, knowing their readiness, etc. One sample statement from one of the pre-service teachers is as follows:

No matter what we are doing, be it presenting a new point or doing exercise, it is essential that we identify the level of the learners and get prepared accordingly.

\subsubsection{L1 Use}

Considerable progress has been achieved in terms of limiting L1 use in the classroom. At the beginning of the term, most pre-service teachers thought that it was impossible to use L2 in the classroom for fear that students would not understand them. However, as time passed by and as they persisted in their use of L2, it became clear that students got used to hearing L2 and started to understand much better. As for L2 use, one of the pre-service teachers remarked that:

In terms of L2 use, at the beginning students had difficulty. They told us to switch back to Turkish. But as time passed by, they got used to it and we had better results. What is more, when they know that you won't turn back to English they listen to you. But if they know that you will explain in Turkish later, they don't listen L2.

From this remark, we can understand that L2 teachers must persist in the use of L2.

\subsubsection{Use of Materials}

Another area where students had significant development is related to materials, both in terms of their use and preparation. At the beginning of the term, pre-service teachers thought that anyting could count as materials and they had a fallacy that everything they find on the Internet can be used in the classroom. However, as time passed by and as their experiences accumulated, they came to see that issues related with materials must be handled with utmost care. One of the pre-service teachers stated that: "Materials rank the second after the teacher in language teaching process."

\subsubsection{Teacher Identity}

It can be said that the practicum serves as a valuable ground for the development of teacher identity. The pre-service teachers stated that they gained a new perspective in which teachers are both teachers and learners. One of the pre-service teachers stated that:

It was definitely beneficial in the formation of teacher identity. One cannot form teacher identity without going into the classroom. Another important factor that enabled us to form our teacher identities was our professors addressing us as "colleagues".

\section{Discussion and Conclusion}

The present study was conducted in order to get an understanding of the issues that emerge from the reflections of pre-service teachers. To do this, continuous interviews and reflection sessions were conducted in the presence of mentors, pre-service teachers, the researcher, and other pre-service teachers. It is generally accepted that 
mentoring generates remarkable amount of collaboration among pre-service and experienced teachers and considerable progess is made by pre-service teachers (Koballa \& Bradbury, 2009). Thus, the present study covers the dialogic nature of the professional development. Pre-service teachers reflected on their own and others' teaching experiences in mentor meetings. These meetings were conducted after every lesson so that no data would be lost. The reflections were based on systematic stimulated recall so that pre-service teachers would recognize not only the important issues from the lesson but also realize problems in their teaching for improving their practices in their coming lessons.

Depending on the results of the study, it can be said that one remarkable problem was related to extreme L1 use in the classroom. At the beginning of the practicum process, most of them used L1 in the classroom for fear that students would not understand them. However, as time went on, they started to use more L2 in the classroom and it was observed that the students got used to hearing English. Another major problem was related to material preparation and use. At the beginning, the pre-service teachers were rather inefficient in materials preparation and use. However, as the process continued, they developed themselves in this regard. Insufficient material use and preparation were also voiced by the mentors of the students.

One of the perennial problems pre-service teachers lived was paying insufficient attention to production. The pre-service teachers in the study are not aware of the importance of production. However, through the end of the practicum process, they started to voice the need for more production in the classroom.

One important issue that emerged from the findings of the study is that the practicum process enhances self-efficacy. This is particularly significant because we know from the literature that self-efficacy is a highly important construct in relation to teacher's positive attitudes (Moradkami et al., 2017). Teacher self-efficacy was found to be related to language learners' achievement Akbari et al., 2008). Similarly, Ghanizadeh and Moafian (2011) demonstrated that teachers with a high level of self-efficacy have higher evaluation ratings from students compared to ones who have low level of self-efficacy. Last bu not the least, a correlation was also found between EFL teachers' English proficiency and self-efficacy (Chacon, 2005; Choi \& Lee, 2016). As such, now that the practicum process contributes to the development of pre-service teachers' self-efficacy, it can be said to play a fundamental role.

The present study also dwelled on the influence of the practicum on the identity development of pre-service teachers. As is known, there is a close relationship between teacher identity and teachers' professional development (Rodgers \& Scott, 2008). In addition, literature shows us that factors like teachers' satisfaction, commitment, motivation and self-efficacy are influenced by teaching identity. (Alsup, 2006; Chong \& Low, 2009). One way in which teacher identity can be approached is the dialogical perspective, which supposed that discourses and ongoing dialogues in social contexts greatly contribute to the development of teacher identity (Smith \& Sparkes, 2008). In literature, there is evidence suppoting this view. Kimmelmann and Lang (2019), for example, focused on the role of cooperative learning in teacher education and found that cooperative learning greatly benefits student teachers. Although this article paid peripheral attention to the identity development of the participants, it was seen that the dialogues between and among pre-service teachers, mentors and the researchers played a significant role in the identity development of the participants. The participants stressed the role of video-recording the lessons and conduction reflections on them.

Another issue that became clear during the practicum process was knowledge of students and the context. The pre-service teachers came to realize the paramount importance knowledge of students and context has in the process of language education, from the planning to the actual practice of lessons.

On the other hand, along with a number of positive developments, there are also areas where pre-service teachers have problems. One of them is not using students' previous knowledge. Pre-service teachers make very little use of brain storming. The second problem is giving feedback and praising. Pre-service teachers seem to have made little progress in terms of giving feedback. They can be supported by the literature. They can be made to read articles about giving feedback. The third issue is the language problems pre-service teachers themselves have, particularly pronunciation. Their language proficiency is generally taken for granted. Nevertheless, during the practicum process, it became clear that they need to improve themselves. Another problem is collecting students' attention. Pre-service teacher fail to collect the attention.

The emerging factors in the present study are generally related to how to deal with the new job. Similar results are reported in the literature. Maaranen et al. (2019), for example, report that the main concerns of beginning teachers are more related to how to conduct the actual teaching whereas as time goes by their concerns shift to other issues such as being busy, workload, heavy demands on them, and well-being. Therefore, longitudinal studies can be conducted the see the changing concerns of pre-service teachers and experienced teachers. 
It is possible to draw a number of suggestions from the present study. In the first place, one-to-one reflection sessions provided valuable data and a context where pre-service teachers can share their experiences dialogically; yet, for large scale quantitative studied the teacher reflection inventories developed by Akbari et al. (2010) or Xu et al. (2015) cen also be used. Another important suggestion based on the findings of the present study and the findings of the study conducted by Tiainen et al. (2018) would be to make reflection with peers and mentors an essential component of the first years of pre-service teachers and to give sufficient time to pre-service teachers to absorb the necessary skills. In Turkish context, Akcan's (2015) study found that there are differences between and among between the content of pre-service teachers' academic courses in their teacher education programme and the conditions they experienced in classrooms. Therefore, a further study can focus on what these differences are and how they affect pre-service teachers' views.

It is generally accepted in literature that reflective practice enables teachers to construct knowledge, to become aware of their own problems, and to become less dependent on outside knowledge (Cousin, 2002). However, as is found by Marcosa et al's (2011) study, pre-service teachers or in-service teachers are not instructed on how to conduct reflection or various types of reflection. Another finding of this study was that there is a discrepancy between what is said and done, and teachers are not provided with sufficient information about reflective practice. Therefore, as part of teacher education programs, reflective practice must become a primary component.

Another interesting study was conducted by Heikonen et al. (2017). They worked on strategies pre-service teachers employ in classroom interaction with pupils during teaching practice periods, which is a scarcely studied topic. In particular, they studied the oft-used strategies student-teachers utilised in classroom interaction and the multiple qualities of these strategies. Their study found that pre-service teachers mainly employ reactive behavioral strategies in the face of demanding situations in the classroom. In a future study that is based on L2 pre-service teachers, such strategies can be the focus.

\section{References}

Akbari, R., Kiany, G. R., Naeeni, M. I., \& Allvar, N. K. (2008). Teachers' teaching styles, sense of efficacy and reflectivity as correlates of students' achievement outcomes. Iranian Journal of Applied Linguistics, 11, $1-28$.

Akbari, R., Behzadpoor, F., \& Dadvand, B. (2010). Development of English language teaching reflection inventory. System, 38, 211-227. https://doi.org/10.1016/j.system.2010.03.003

Akbari, R. (2007). Reflections on reflection: A critical appraisal of reflective practices in L2 teacher education. System, 35, 192e207. https://doi.org/10.1016/j.system.2006.12.008

Akcan, S. (2016). Novice non-native English teachers' reflections on their teacher education programmes and their frst years of teaching. PROFILE Issues in Teachers' Professional Development, 18(1), 55-70. https://doi.org/10.15446/profile.v18n1.48608

Alsup, J. (2006). Teacher identity discourses: negotiating personal and professional spaces. Mahwah, New Jersey: Lawrence Erlbaum.

Borg, S. (2003). Teacher cognition in language teaching: A review of research on what teachers think, know, believe, and do. Language Teaching, 36, 81e109. https://doi.org/10.1017/S0261444803001903

Borg, S. (2011). Language teacher education. J. Simpson, the Routledge handbook of applied linguistics. New York: Routledge.

Chacon, C. T. (2005). Teachers' perceived efficacy among English as a foreign language teachers in middle schools in Venezuela. Teaching and Teacher Education, 21, 257-272. https://doi.org/10.1016/j.tate.2005.01. 001

Chang-Kredl, S., \& Kingsley, S. (2014). Identity expectations in early childhood teacher education: pre-service teachers' memories of prior experiences and reasons for entry into the profession. Teaching and Teacher Education, 43, 27-36. https://doi.org/10.1016/j.tate.2014.05.005

Choi, E., \& Lee, J. (2016). Investigating the relationship of target language proficiency and self-efficacy among nonnative EFL teachers. System, 58, 49-63. https://doi.org/10.1016/j.system.2016.02.010

Chong, S., \& Low, E. (2009). Why I want to teach and how I feel about teachingeformation of teacher identity from pre-service to the beginning teacher phase. Educational Research for Policy and Practice, 8(1), 59-72. https://doi.org/10.1007/s10671-008-9056-z 
Clarke, D., \& Hollingsworth, H. (2002). Elaborating a model of teacher professional growth. Teaching and teacher education, 18, 947-967. https://doi.org/10.1016/S0742-051X(02)00053-7

Creswell, J. W. (2003). Research design: Qualitative, quantitative and mixed methods approaches (2nd ed.). London, UK: Sage Publications.

Dewey, J. (1933). How we think: A restatement of the relation of reflective thinking to the educative process. Boston, MA: Heath

Dörnyei, Z. (2007). Research methods in applied linguistics: Quantitative, qualitative and mixed methodologies. Oxford, Uk: Oxford University Press.

Farrell, T. S. C. (2016). The practice of encouraging TESOL teachers to engage in reflective practice: An appraisal of recent research contributions. Language Teaching Research, 20, 223-247. https://doi.org/10. $1177 / 1362168815617335$

Gao, X. (2008). Teachers' professional vulnerability and cultural tradition: a Chinese paradox. Teaching and Teacher Education, 24(1), 154-165. https://doi.org/10.1016/j.tate.2006.11.011

Gass, S. M., \& Mackey, A. (2000). Stimulated recall methodology in second language acquisition. Mahwah, NJ: Erlbaum.

Ghanizadeh, A., \& Moafian, F. (2011). The relationship between Iranian EFL teachers' sense of self-efficacy and their pedagogical success in language institutes. The Asian EFL Journal, 13, 249-272.

Hudson, P., Usak, M., Fancovicova, J., Erdogan, M., \& Prokop, P. (2010). Preservice teachers' memories of their secondary science education experiences. Journal of Science Education \& Technology, 19(6), 546-552. https://doi.org/10.1007/s10956-010-9221-z

Maaranen, K. Kynäslahti, H. Byman, R. Jyrhämä, R., \& Sintonen, S. (2019). Teacher education matters: Finnish teacher educators' concerns, beliefs, and values, European Journal of Teacher Education. https://doi.org/10. $1080 / 02619768.2019 .1566317$

Kim, H., \& Hannafin, M. J. (2008). Situated case-based knowledge: An emerging framework for prospective teacher learning. Teaching and Teacher Education, 24(7), 1837e1845. https://doi.org/10.1016/j.tate. 2008.02.025

Kimmelmann, N., \& Lang, J. (2019). Linkage within teacher education: Cooperative learning of teachers and student teachers. Journal of European Teacher Education, 42(1), 52-64. https://doi.org/10.1080/02619768. 2018.1547376

Koballa, T. R., \& Bradbury, L. U. (2009). Mentoring in support of science teaching. In A. Collins, \& N. Gilespie (Eds.), The continuum of secondary science teacher preparation: Knowledge, questions and research recommendations (pp. 171-185). Rotterdam, The Netherlands: SensePublishing. https://doi.org/10.1163/ 9789087908041_013

Körkkö, M., Kyro-Ammala, O., \& Turunen, T. (2016). Professional development through reflection in teacher education, Teaching and Teacher Education, 55, 198-206.

Kumaravadivelu, B. (2006). Understanding language teaching: From method to postmethod. New Jersey: Lawrence Erlbaum Associates, Inc

Heikonen, L. Toom, A., Pyhältö, K., Pietarinen, J., \& Soini, T. (2017). Student-teachers' strategies in classroom interaction in the context of the teaching practicum, Journal of Education for Teaching, 43(5), 534-549. https://doi.org/10.1080/02607476.2017.1355080

Levin, B., \& He, Y. (2008). Investigating the content and sources of teacher candidates' personal practical theories (ppts). Journal of Teacher Education, 59(1), 55-68. https://doi.org/10.1177/0022487107310749

Mackey, A., \& Gass, S. M. (2005). Second language research: Methodology and design. Mahwah, Us: Lawrence Erlbaum Associates.

Marcosa, J. M., Sancheza, E., \& Tillema, H. H. (2011). Promoting teacher reflection: What is said to be done. Journal of Education for Teaching, 37(1), 21-36. https://doi.org/10.1080/02607476.2011.538269

McKenzie, P., \& Santiago, P. (2005). Teachers matter: Attracting, developing and retaining effective teachers. Paris: Organisation for Economic Cooperation and Development.

Milrood, R. (1999). A module for English language teacher trainers. British Council: Moscow. 
Moradkhani, s. Raygan, A., \& Moein, M. S., (2017). Iranian EFL teachers' reflective practices and self-efficacy: Exploring possible relationships. System, 65, 1-14. https://doi.org/10.1016/j.system.2016.12.011

Pence, H. M., \& Macgillivray, I. K. (2008). The impact of an international field experience on preservice teachers. Teaching and Teacher Education, 24(1), 14e25. https://doi.org/10.1016/j.tate.2007.01.003

Rodgers, C. R., \& Scott, K. H. (2008). The development of the personal self and professional identity in learning to teach. In M. Cochran-Smith, S. FreimanNemser, D. J. McIntyre, \& K. E. Demers (Eds.), Handbook of research on teacher education (3rd ed., pp. 732-755). New York: Routledge.

Ryder, J. (2012). Promoting reflective practice in continuing education in France. ELT Journal, 66(2), 175-183. https://doi.org/10.1093/elt/ccr032

Singh, P. 2008. Oral and written reflection in practice management: An action research approach. Systematic Practitioner Action Reserch, 21, 171-85. https://doi.org/10.1007/s11213-008-9089-5

Smith, B., \& Sparkes, A. C. (2008). Contrasting perspectives on narrating selves and identities: An invitation to dialogue. Qualitative Research, 8(1), 5e35. https://doi.org/10.1177/1468794107085221

Tiainen, O., Korkeamäki, R. T., \& Jean Dreher, M. (2018) Becoming Reflective Practitioners: A Case Study of Three Beginning Pre-service Teachers, Scandinavian Journal of Educational Research, 62(4), 586-600. https://doi.org/10.1080/00313831.2016.1258673

Turunen, T. A., \& Tuovila, S. (2012). Mind the gap. Combining theory and practice in a field experience. Teaching Education, 23(2), 115-130. https://doi.org/10.1080/10476210.2012.669751

Uitto, M. (2011). Storied relationships: students recall their teachers. Oulu: University of Oulu.

Xu, J. Li, B., \& Curtis, A. (2015). Validating an English language teaching reflection inventory in a Chinese EFL context. System, 49, 50-60. https://doi.org/10.1016/j.system.2014.10.014

Winchester, T. M., \& Winchester, M. K. (2014). A longitudinal investigation of the impact of faculty reflective practices on students' evaluations of teaching. British Journal of Educational Technology, 45, 112-124. https://doi.org/10.1111/bjet.12019

Zhang, L. J., \& Said, B. S. (2014). Toward a global understanding of local initiatives in language teaching and teacher education: Global rules, local roles. In B. S. Said, \& L. J. Zhang (Eds.), Language teachers and teaching: Global perspectives, local initiatives. London \& New York: Routledge Taylor and Francis.

\section{Copyrights}

Copyright for this article is retained by the author(s), with first publication rights granted to the journal.

This is an open-access article distributed under the terms and conditions of the Creative Commons Attribution license (http://creativecommons.org/licenses/by/4.0/). 